\title{
PUBLIC-SOCIAL PARTNERSHIP FOR ENHANCING THE VALUE OF HUMAN CAPITAL IN LOCAL PRODUCTION SYSTEMS LODZ REGION CASE STUDY
}

\begin{abstract}
Inter-sectoral cooperation is one the most important elements of contemporary, place-based policy. Deriving from the conditions of the environment, also the global one, local actors should join their forces by investing in the resources determining today's' development knowledge and human capital - in the most effective way. However, internal national or regional conditions, very often do not allow for efficient adaptation of development mechanisms, even when they have been already tested in other places. By narrowing the area of analysis to the relationships between territorial self-government and non-governmental organisations, this paper is an attempt to answer the question on what scale, in the Polish conditions, public-social partnerships are being built and what is their scope. Analysis concerns the institutions involved in the investment in knowledge and human capital, operating in the region of Lodz.

Indexing
\end{abstract}

Keywords: human capital, partnership, NGOs, region.

\section{INTRODUCTION}

Challenges and needs of public-social partnership are formulated, first and foremost, in social economics. The line of thinking is strongly territorially embedded, it makes references to local communities, which mobilise and shape economic processes through social, cultural and religious values cherished by these communities. Hence, as we read in J. Hausner, it is hard to speak of a universal pattern of social economics (Hausner 2006: 13). However, when formulating a synthetic definition of the term, we may adopt B. Roelants's proposal, which assumes that social economics is characterised by (Hausner 2008: 9):

- solidarity and social cohesion,

- social responsibility and involvement,

- democracy and participation,

- autonomy and independence.

* University of Lodz, Faculty of Economics and Sociology, Department of Regional Economy and Environment. 
In the context of the above mentioned criteria, it is interesting to find out, which of them already determine and which still de-stimulate regional development. Public-social partnership is shaped at the level of formal and informal relationships and institutions. Under such boundary conditions, studies were conducted where we identified the circumstances, quality and scope of such local partnerships. Analyses took place in Lodz voivodeship and the studies were limited to NGOs dealing with investing in knowledge and human capital ${ }^{1}$. Thus, the direct aim of the paper is to identify the scale of territorial self-government units in the region, which avail themselves of public-social partnership in activities designed to improve the quality of human capital and the scope of the activities of NGOs engaged in such activity.

\section{TERRITORIAL ORIENTATION OF REGIONAL POLICY}

Dynamics and social and economic development of a region are determined by the competitiveness of its economic operators. It does not mean, however, that the environment is passive vis-à-vis economic operators based in a given region. The fact is that location decisions are nowadays strictly dependent on the quality of the environment (entrepreneurial milieu), on the development of local production system. A mature local production system "is a collection of selected relations with chosen partners that forms part of companies' market relations. The main driving force behind it is the wish to reduce the uncertainty of operations" (Jewtuchowicz 1997: 14). The presence of systems, such as networks of businesses, business environment institutions, non-governmental organisations, public institutions and relationships among them, availability of adequate labour resources, technical and social infrastructure ensuring appropriate living standard, all of these are decisive for the attractiveness of a business location.

Development coordination models used so far in the European Union turned out to be little effective. In particular, when it comes to the use of territorial capital, including the power and potential of local production systems. Present changes in the approach to the implementation of regional policy in Europe are evolutionary and determined mainly by the drive of public authorities to improve the efficiency of activities for the development of countries and regions. Seeking optimum solutions aims at effective use of globalisation effects and "new" production factors: knowledge and human capital, on the one hand, and local resources and conditions, on the other hand'.

\footnotetext{
${ }^{1}$ For more see further in the paper.

${ }^{2}$ We can observe it in the evolution of regional policy with theoretical foundations for shaping the conditions for its implementation dating back to the 1960s. These conditions underwent considerable transformations. We can follow the evolution by making references to notions, which provide proper characteristics: "Europe of the regions", "Europe with regions", "Regions for Europe", or the present Place-based Policy.
} 
Striving for territorial cohesion ${ }^{3}$, the postulate is to balance and look at development resources from two perspectives. Nowadays, the approach is referred to as place-based policy (Nowakowska 2011; Jewtuchowicz 2005; Sokołowicz 2013: 59-92). It attributes principal role to the ability of using local resources and potential by attaching key importance to their specificity, uniqueness, and ability to generate income. "A place-based policy is a long-term strategy aimed at tackling persistent underutilisation of potential and reducing persistent social exclusion in specific places through external interventions and multilevel governance. It promotes the supply of integrated goods and services tailored to contexts, and it triggers institutional changes" (Barca 2009: VII). Thus, a place-based policy can generally be defined as (Barca 2009: 5):

- a long-term development strategy whose objective is to reduce persistent inefficiency (underutilisation of the full potential) and inequality (share of people below a given standard of well-being and/or extent of interpersonal disparities) in specific places,

- through the production of bundles of integrated, place-tailored public goods and services 14, designed and implemented by eliciting and aggregating local preferences and knowledge through participatory political institutions, and by establishing linkages with other places, and

- promoted from outside the place by a system of multilevel governance where grants subject to conditionalities on both objectives and institutions are transferred from higher to lower levels of government.

Territory and its inhabitants, users, institutions are perceived as entities able to really shape their future and determine development processes. In fact, local conditionalities, organisational arrangements, commitment are largely decisive for competitive capabilities of a territorial unit, even in the face of omnipresent globalisation. Place-based approaches use local actors and resources as assets in a collaborative process to address issues as they are experienced within a geographic space, be it a neighbourhood, a region or an eco-system. The main point of characteristics of place-based processes, it is: collaborative; opportunity-driven, dependant on local talent, resources and constraints; evolving process due to an adaptive learning process and stakeholder interests; attempt to integrated across silos, jurisdictions and dimensions of sustainability; leverage assets and knowledge through shared ownership of the initiative (Lamontagne, Carr, Stoney 2011).

${ }^{3}$ Communication from the Commission to the Council, the European Parliament, the Committee of the Regions and the Economic and Social Committee. Green Paper on Territorial Cohesion. Turning territorial diversity into strength $\{$ SEC(2008) 2550\} Commission of European Communities, Brussels on 6.10.2008 COM(2008) 616 final. 


\section{CONDITIONS FOR USING PUBLIC-SOCIAL PARTNERSHIP TO FOSTER HUMAN CAPITAL IN THE REGION METHODOLOGY OF STUDIES}

In modern economy determined with network relationships, in a network society with horizontal system of interdependences, institutional structure is the building block of developing and maintaining key nods in the network. It coordinates and enables efficient operations; provides proper social climate based on trust, responsibility, competences and creating "business atmosphere". It is also a complementary element for building social capital.

Institutional environment can be understood very broadly and then we often use the term of "institutional structure", which should be interpreted as "rules of the game in a given society or, in other words, conditionalities created by a man that shape interactions among people" (Pietrzyk 2000: 26). Under such interpretation, the structure includes historical conditions, traditions, customs, rites, conduct norms for people, legal, educational, fiscal systems, etc. institutional structure may also be understood narrowly, i.e., as:

- public institutions (e.g.: public authorities at various levels, universities),

- public-private institutions (e.g.: regional development agencies),

- NGOs (e.g.: foundations and associations, which support entrepreneurship and innovation, social welfare institutions),

- private sectors associations (e.g.: business organisations: chambers of craftsmen, professional associations),

- private institutions (e.g.: economic organisations, banks, insurance agencies, venture capital funds).

The catalogue includes also institutions at the borderline of private and public sector: non-governmental institutions of the civic sector. Non-governmental sector institutions are an important link in Polish economy, which supports both public entities and private sector in current, horizontal activities.

There are various terms and definitions used to describe these institutions: third sector organisations, intermediary organisations, social organisations, etc. ${ }^{4}$ Their diversity and multitude of definitions are reflected in types and names used in Anglo-Saxon countries and in the USA, where they are the most frequently referred to as non-governmental organisations (NGO). Common characteristics of the majority of them are:

4 "Entities in this sector are usually referred to as third sector organisations or non-governmental organisations, although there are many other terms, such as: non-profit organisations (non for profit), independent organisations, social organisations, charitable organisations, voluntary organisations, civic organisations or public benefit organisations". For more see the paper by J. Chądzyński (2014: 119-151). 
- non-profit activities (which does not mean that their operations are free from market motivations, they usually operate in a competitive environment, economic efficiency decides on the effectiveness of the organisation and the ability to deliver the mission (statutory tasks)),

- sovereignty and self-management,

- organisational structure and formal registration,

- structural independence from public authorities (in terms of politics, finance, personal involvement and tasks, the matters are much more complex).

On top of that, there are some functions (or roles), which can be attributed to such entities. In literature we can find the below functions the most frequently (Wygnański 2005: 11-14; Załuska 1998: 38-40):

- assistance - connected with meeting basic needs of humans, such as elimination of hunger, giving the sense of safety,

- affiliation - connected with the need of a person to belong to a social group,

- expressive - connected with human need of self-fulfilment,

- care and education - connected with shaping human personality throughout her/his life,

- integration - connected with involvement into building social relationships, developing social skills of establishing relations and making agreements inside a social group and among groups.

NGOs operate in various areas and sectors. Some of them have specialised in activities in support of entrepreneurship, knowledge and technology transfer and commercialisation of new technologies, investing in human capital and improving competitiveness of the economy, the so called centres of innovation and entrepreneurship (Mertel 2001: 101-124; Cebo, Pawlas 2000: 17-27; Matusiak 1998, 2000, 2001) are established to deliver tasks such as (Matusiak 2001: 252):

- supporting entrepreneurship, self-employment, facilitating and assisting start-ups, promotion and improving the competitiveness of SMEs,

- creating conditions for the transfer of new technological solutions into the economy and implementing innovative undertakings,

- improving the quality of human resources through education, training, advisory services, provision of information and disseminating positive models,

- managing resources and delivering infrastructural projects,

- developing cooperation networks and partnerships among various entities, which contribute to the dynamics of growth and increase in the welfare of people,

- facilitating the diffusion of knowledge,

- supporting knowledge transfer and commercialisation.

In the knowledge-based economy highly skilled human resources, which largely determine social and economic development are extremely important (Markowska 2007: 35-45; Becker 1990: 44-54). They make the capital, which is often referred to as superior to all other constituents of the knowledge-based economy (Strahl, Markowska 2007: 113), as an asset embodied 
in people, whose quality is decisive for the welfare of regional community (Strahl, Markowska 2007: 113-114). Traditionally, investment in human capital are made by public entities (through the system of education). Obviously, it is a narrow perception of how development policy can be supported in this sense. From the point of view of entities involved, huge challenges and opportunities have been identified for private entities (companies and households) and entities in the non-governmental sector.

Beyond any doubt, central public authorities deliver policy designed to adjust the characteristics of human capital across Poland to the needs of the market to improve competitive potential. However, there may be some misgivings, whether, from the perspective of regional authorities, the goal suffices as it does not make any presumptions concerning the efficiency of the investment from regional perspective since the efficiency is achieved by balancing the effects for the entire economy. That is why from the point of view of the voivodeship, it is right to identify and pursue its own policy of fostering human capital, in line with national policy but bringing effects for the region, where the investment actually takes place. Nevertheless, the regions do not pursue individual, empowered human resources development policy in Poland (Przygodzki 2013: 134-166). Moreover, one may easily have an impression that possibilities to use and engage entities from the so called third sector for that purpose are also marginalised. Hypotheses may even be proposed that local self-governments do not fully take advantage of the potential of local non-governmental organisations in the area of enhancing the quality of human resources while the organisations are not always able to exploit opportunities of cooperation with local authorities and, by that, they do not use the possibilities to develop themselves and the territory. The aspect was developed and analysed in details to identify the situation on the side of the public sector and of the NGOs. The studies were conducted in the Lodz Region.

The main objective of the study was, on the one hand, the identification of territorial self-government units in the region, which use public-social partnership in actions aimed at the fostering of human capital. On the other hand, we wanted to explore the scale and scope of what NGOs involved in the field are doing. To this end, we formulated five major research questions:

1. Is there any inter-sectoral collaboration (local self-government - NGOs) in investment in knowledge and human capital? If yes, what is its scope?

2. Do local self-governments collaborate with NGOs in human capital development? In which areas?

3. How do local self-governments assess the activities of NGOs in human capital development?

4. What are the benefits, in the area of investment in knowledge, of the collaboration for NGOs and self-governments but, most of all, for local communities?

5. What are the main barriers to collaboration of local self-governments with NGOs. 
To answer the above questions we conducted a questionnaire-based study addressed to both representatives of local self-governments and NGOs involved in the improvement of human capital development in the Lodz region ${ }^{5}$. First we studied all counties and communes from the Lodz voivodeship, 24 counties and 177 communes, respectively, including 18 urban communes, 25 urban-rural communes, and 134 rural communes, in total 201 territorial self-government units. Questionnaires were sent back by 180 counties and communes ( 22 counties, 18 urban communes, 18 urban-rural communes, and 122 rural communes), meaning the rate of return was $89.6 \%$.

NGOs represent very differentiated fields of activity, a substantial part of them are involved in the development of human capital. From the perspective of the goals of the project, surveys were planned and conducted in these deliberately selected organisations, which focus mostly on interventions into the quality of human capital. In particular, we studied organisations dealing with ${ }^{7}$ :

- schools or extra-mural education,

- training and vocational counselling,

- improving innovation in entities operating in a given territorial self-government unit,

- developing interests and hobbies in the local community,

- promoting physical training and healthy lifestyle,

- promoting and developing culture in a given territorial unit,

- promotion and protection of health,

- mobilising local community and supporting the development of entities which join local community for a common purpose.

\section{ACTIVITIES OF NGOS IN THE AREA OF HUMAN CAPITAL FOR LOCAL PRODUCTION SYSTEMS}

Investing in people in third sector institutions does not give the sense of organisational stability. Hence, even though the selection of respondents was not accidental, being guided by the criterion of investment in human capital, studied organisations usually pointed to promoting physical training and healthy lifestyle in the first place and placed knowledge transfer at distant positions. A substantial portion of these entities also mobilise local communities, support the development of social capital, crucial infrastructure for the transfer of knowledge and coordination of the behaviour

\footnotetext{
${ }^{5}$ Results will be presented further in the paper.

${ }^{6}$ The rate of return was $91.7 \%$ for a county, $100 \%$ for urban communes, $98.4 \%$ for rural communes and the lowest, $72 \%$ for urban-rural communes.

${ }^{7}$ We used a broad definition of human capital identified from the point of view of needs and areas of desired investment (Przygodzki, Nowakowska, Sokołowicz 2011: 44).
} 
of local actors. Investment directly linked to manufacturing and knowledge ranked much lower; educational operations are pursued by ca. $40 \%$ of entities, training and advisory entities by ca. $20 \%$ and purely information ca. $16 \%$. The area is, on the one hand, monopolised by the public sector in education and a strong market of training and advisory services available from the private sector, on the other. The sectoral structure, however, should not be assessed in terms of negative or positive categories. Conclusions can be drawn from postulates addressed to the public sector and the NGOs. Public sector institutions should be more sensitive and remember huge responsibility for the organisation of education-related services. On the other hand, it is a challenge for the non-governmental sector, in particular in a knowledge-based economy, which must bear market needs in mind and adjust their offer to market challenges, which would transform them from service providers responding to the needs into those who create these needs. Thus, they can effectively impact the quality of local entrepreneurial environment.

Table 1

Activity areas of NGOs collaborating with territorial self-government units included in the study $(174=100 \%)$

\begin{tabular}{|l|c|}
\hline \multicolumn{1}{|c|}{ Types of activities pursued by NGOs } & $\begin{array}{c}\text { Proportion of or- } \\
\text { ganisations pursu- } \\
\text { ing the activity }\end{array}$ \\
\hline $\begin{array}{l}\text { training and advisory activities (training courses, vocational counselling, } \\
\text { foreign language courses for people in the commune, also for local entre- } \\
\text { preneurs and unemployed) }\end{array}$ & $93.1 \%$ \\
\hline $\begin{array}{l}\text { disseminating information, in particular to improve innovation of entities } \\
\text { in a commune (private, public, other NGOs) }\end{array}$ & $59.8 \%$ \\
\hline $\begin{array}{l}\text { educational activity, connected with schools and supporting the develop- } \\
\text { ment of inhabitants' interests and hobbies through extra-mural education }\end{array}$ & $46.6 \%$ \\
\hline $\begin{array}{l}\text { promoting physical training and healthy lifestyle (amateur sports teams, } \\
\text { organisation of sports tournaments, etc.) }\end{array}$ & $40.8 \%$ \\
\hline protection and promotion of health & $20.1 \%$ \\
\hline $\begin{array}{l}\text { mobilising local communities and supporting their development (im- } \\
\text { proving individual involvement, promoting joint activities in communes) }\end{array}$ & $16.1 \%$ \\
\hline other (mainly: "culture and arts" and "order and safety" & $14.9 \%$ \\
\hline
\end{tabular}

Source: own study.

The present structure of activity areas of NGOs determines the types of cooperation, which, in most cases, take the simplest shape of financial dimension. Self-governments consider non-governmental entities to be their sub-contractors 
in implementing tasks entrusted to them. Only when cooperation takes place with entities from training and advisory, information or education areas there is some exchange of information and consultancy involved with respect to activities undertaken by both parties. Then they do not limit themselves to assistance in implementing public tasks. Generally, attention should be paid to relatively rare cases when self-governments take advantage of the possibility of entrusting their public tasks to NGOs. That is the effect of rather little engagement of local non-governmental entities at the stage of developing plans relating to possibilities and needs to cooperate and coordinate activities ${ }^{8}$. The results of studies let us conclude that the responsibility for the situation rests with both, the public sector and the NGOs.

Table 2

Types of cooperation between self-governments and NGOs $(160=100 \%)$

\begin{tabular}{|c|c|c|c|c|c|c|c|c|c|}
\hline \multirow[b]{2}{*}{ Activity area } & \multicolumn{9}{|c|}{ Types of cooperation } \\
\hline & 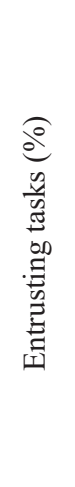 & 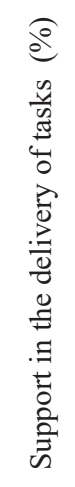 & 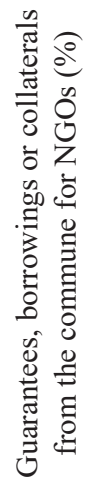 & 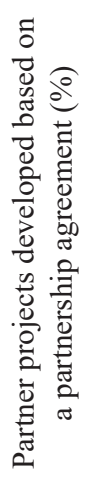 & 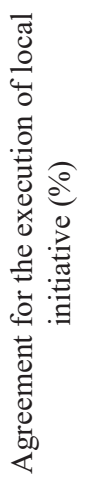 & 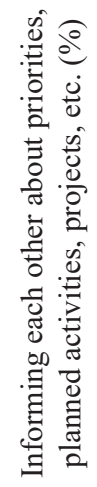 & 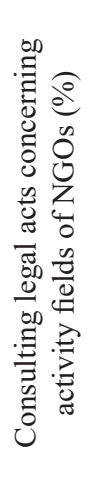 & 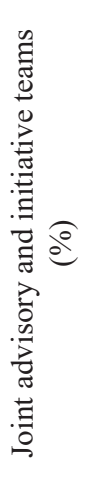 & $\frac{\widehat{o}}{\stackrel{d}{0}}$ \\
\hline 1 & 2 & 3 & 4 & 5 & 6 & 7 & 8 & 9 & 10 \\
\hline $\begin{array}{l}\text { Training and advi- } \\
\text { sory activities }\end{array}$ & 1.3 & 7.5 & 0.0 & 2.5 & 0.0 & 13.1 & 6.9 & 3.8 & 4.4 \\
\hline $\begin{array}{l}\text { Provision and } \\
\text { disseminating of } \\
\text { information }\end{array}$ & 0.6 & 8.8 & 0.0 & 1.9 & 1.3 & 14.4 & 5.0 & 2.5 & 1.9 \\
\hline $\begin{array}{l}\text { Educational ac- } \\
\text { tivities }\end{array}$ & 7.5 & 15.6 & 0.6 & 1.3 & 0.0 & 16.3 & 10.6 & 2.5 & 3.1 \\
\hline $\begin{array}{l}\text { Promoting phys- } \\
\text { ical training and } \\
\text { healthy lifestyle }\end{array}$ & 39.4 & 65.0 & 1.3 & 1.9 & 3.1 & 41.9 & 37.5 & 11.9 & 5.0 \\
\hline
\end{tabular}

${ }^{8}$ The conclusion is even more justified by the fact that for years in Poland we have been promoting market model of management in the public sphere (New Public Management) also public governance is getting more and more relevant. Hence it is hard to explain the situation with the lack of understanding, best practices or negative attitude of the environment. 
Table 2 (cont.)

\begin{tabular}{|l|c|c|c|c|c|c|c|c|c|}
\hline \multicolumn{1}{|c|}{1} & 2 & 3 & 4 & 5 & 6 & 7 & 8 & 9 & 10 \\
\hline $\begin{array}{l}\text { Protection and } \\
\text { promotion of } \\
\text { health }\end{array}$ & 13.1 & 30.6 & 1.3 & 0.6 & 1.9 & 20.0 & 15.6 & 9.4 & 2.5 \\
\hline $\begin{array}{l}\text { Mobilising local } \\
\text { communities and } \\
\text { supporting their } \\
\text { development }\end{array}$ & 10.0 & 21.9 & 0.6 & 2.5 & 5.6 & 21.3 & 16.3 & 4.4 & 2.5 \\
\hline $\begin{array}{l}\text { Public order and } \\
\text { safety }\end{array}$ & 0.0 & 1.9 & 0.0 & 0.0 & 0.0 & 2.5 & 1.3 & 1.3 & 0.6 \\
\hline $\begin{array}{l}\text { Cultural activities } \\
\text { and promotion of } \\
\text { culture }\end{array}$ & 1.9 & 8.1 & 0.0 & 0.0 & 0.0 & 6.3 & 5.6 & 3.8 & 0.6 \\
\hline
\end{tabular}

In grey we marked types of cooperation, which have scored more than $10 \%$ of respondents' answers.

Source: own study.

Table 3

Scores of NGOs activities in selected areas

\begin{tabular}{|l|c|c|c|c|c|c|c|}
\hline \multirow{2}{*}{ Activity area } & \multicolumn{7}{|c|}{ Score ("school" grades from 1 to 6) } \\
\cline { 2 - 8 } & $\mathbf{1}(\mathbf{\%})$ & $\mathbf{2}(\mathbf{\%})$ & $\mathbf{3}(\mathbf{\%})$ & $\mathbf{4}(\mathbf{\%})$ & $\mathbf{5}(\mathbf{\%})$ & $\mathbf{6}(\mathbf{\%})$ & $\begin{array}{c}\text { Aver- } \\
\text { age }\end{array}$ \\
\hline $\begin{array}{l}\text { Training and advisory activity } \\
(48=100 \%)\end{array}$ & 16.7 & 16.7 & 14.6 & 35.4 & 10.4 & 6.3 & 3.25 \\
\hline $\begin{array}{l}\text { Provision and disseminating infor- } \\
\text { mation (53=100\%) }\end{array}$ & 9.4 & 17.0 & 20.8 & 37.7 & 13.2 & 1.9 & 3.34 \\
\hline Educational activity (69=100\%) & 4.3 & 13.0 & 21.7 & 39.1 & 15.9 & 5.8 & 3.67 \\
\hline $\begin{array}{l}\text { Promoting physical training and } \\
\text { healthy lifestyle (152=100\%) }\end{array}$ & 0.7 & 0.0 & 7.2 & 29.6 & 40.8 & 21.7 & 4.75 \\
\hline $\begin{array}{l}\text { Protection and promotion of health } \\
(81=100 \%)\end{array}$ & 3.7 & 7.4 & 14.8 & 28.4 & 27.2 & 18.5 & 4.23 \\
\hline $\begin{array}{l}\text { Mobilising local communities and } \\
\text { supporting their development } \\
(85=100 \%)\end{array}$ & 2.4 & 15.3 & 11.8 & 32.9 & 25.9 & 11.8 & 4.00 \\
\hline Public order and safety (5=100\%) & 0.0 & 0.0 & 40.0 & 20.0 & 20.0 & 20.0 & 4.20 \\
\hline $\begin{array}{l}\text { Culture and culture promotion } \\
(15=100 \%)\end{array}$ & 0.0 & 0.0 & 13.3 & 13.3 & 53.3 & 20.0 & 4.80 \\
\hline
\end{tabular}

Source: own study. 


\section{INSTITUTIONAL PROXIMITY FOR PUBLIC-SOCIAL PARTNERSHIP}

Intersectoral cooperation has for a long time been treated as an opportunity, which determines development processes, in particular when we make reference to the theory and concept of endogenous growth based on internal resources of territorial units. Nevertheless, the scope of partnerships, both public-social and public-private, is still clearly limited. In order to encourage and mobilise self-governments to engage into collaboration and to more frequently use organised entities to undertake activities addressed to local communities, on 24 April 2003 Polish government adopted the Law on Public Benefit Activity and Volunteerism, which imposes a duty to comply formally with the principle of partnership. The Legislator obliged, inter alia, territorial self-government units to adopt annual or multiannual programmes of cooperation with NGOs an d entities listed in Art. 3 para. 3 of the Law.

It is a highly effective tool because it is binding, however, the form, scope and quality and the efficiency of intersectoral partnership are equally important. Practical evidence, based on results of surveys, shows that the tool is marginalised, simplified and boils down to the drafting of a formal document, which provides little basis for the policy and public interventions. Hence $96.1 \%$ of territorial self-government units covered by the study admitted they have cooperation programmes. Most of them are annual - 155 (86.1\%), only 18 (10\%) territorial self-government units declared they have multiannual programmes. In vast majority of cases the programmes are limited to operational, short-time management. Non-governmental entities are treated as a tool to deliver own tasks, as service providers contracted for a fiscal year. Bearing in mind that we are speaking of local entities, organisations, which emerged and are deeply rooted in local communities, we may conclude that such short-term strategies do not contribute to the stabilisation of the non-governmental sector, improving its credibility, resilience and, finally, innovativeness. Observations make us believe that a substantial part of creativity, willingness to work, unconventional but at the same time effective activities of NGOs depend on the enthusiasm and personal characteristics of their leaders. However, limited cooperation framework (multiplied by financial problems, involved risk and uncertainty of the future, the sense of isolation and being in the position of a client to the administration) usually effectively de-motivate and discourage from further operations. Interestingly enough, multiannual (5- and 3-year) programmes were more often declared by urban-rural communes and counties than by small rural communes and towns (respectively $20 \%, 18 \%$ and $8 \%, 7 \%$ ). In $88.9 \%$ of cases, self-governments claimed they invited non-governmental entities to collaborate in the development of cooperation programmes, however, usually ( $76.9 \%$ of cases) consultations consisted in the presentation of already prepared draft cooperation programmes to the NGOs, which were expected to give their opinions. Less than 
$30 \%$ of self-governments included in the study received proposals concerning priority tasks from Third Sector organisations. As rightfully noticed by J. Chądzyński "This is a worrying sign as NGOs represent the needs of inhabitants and they often emerge as a result of the inability of public entities operating in a given area to meet the needs of local communities" (Chądzyński 2014: 126). It is important that when the two parties really collaborated on drafting inter-sectoral cooperation framework, self-governments took account of the suggestions and postulates of NGOs. Definitely negative experience was declared by $6.3 \%$ of respondents. Thus, when there are genuine attempts made to establish cooperation links, the parties wish to collaborate as partners and strive for mutual approval.

\section{CONCLUSIONS}

By launching cooperation with NGOs to support the transfer of knowledge, territorial self-government admits it benefits in two ways. Firstly, these are benefits typical of the so called contract outsourcing, i.e. improved competence resulting from the utilisation of partner's knowledge, wider offer and possibilities to act with simultaneous savings in time as the self-government may focus on strategic aspects. On top of that, there are promotional effects due to the increased number of parties involved (in particular outside of the public sector), who are interested in the efficiency of their operations.

Secondly, territorial self-government units list social benefits, mainly the following: improved quality of life, enhanced citizens' awareness and their mobilisation to act. These benefits can also be perceived as investments in infrastructure that facilitates the transfer of knowledge, both explicit and tacit.

On the other hand, NGOs assess the benefits of cooperation with the self-government from their internal (organisational) perspective and from the perspective of benefits experienced by the inhabitants as perceived by the NGOs. The major organisational benefits highlight financial support to their activities. Respondents also claim that partnership motivates them to improve their performance. Interestingly, organisations stress the benefit of knowledge transfer to them; substantive and organisational support of self-governments is relevant. Other benefits relate to infrastructural conditions and services connected with technical aspects of NGOs operations (available space, legal support, promotion, etc.).

Benefits to inhabitants, which according to the respondents result from the cooperation between the NGOs and self-government, consist in positive impact upon inhabitants' social competences. They mean, first of all, mobilising and integrating the local community and improving the availability of services (through wider product and production offer). 
Summing up, we should also highlight the major critical conclusions from the study. They focused mostly on:

- little propensity of the public sector to engage NGOs into the delivery of services addressed to human capital and the transfer of knowledge,

- lack of trust in NGOs stemming mainly from their instability,

- poor strategic management in the area of building public-social relations, in particular with the NGOs (despite existing legal tools to this effect),

- importance of non-material factors in local development underestimated by self-governments. As a result, local development strategies very rarely refer to investing in knowledge and strategic goals labelled as "human capital" include non-market services,

- usually passive attitude of NGOs to the building of public-social partnership, which limits to applying for subsidies without getting to know each other and understanding the need to act, presenting own development plans or lobbying for their implementation,

- low assessment, by self-governments, of NGOs operations in areas connected with fostering human capital,

- little developed specialisation of NGOs in activities designed to support human capital development and the transfer of knowledge.

Public-social partnership is surely far from easy. Like any cooperation it requires some investment, it does not happen by itself. Benefits and advantages of partnerships have been listed on many occasions but the major difficulty lies in making the cooperation a reality. Theoretical issues have been analysed many times, to quote the model of Public Governance as an example. Thus, the parties are aware of benefits, however, the costs or sometimes perhaps the lack of skills still prevent them from joining forces to achieve common goals.

\section{REFERENCES}

Barca F. (2009), An agenda for a reformed cohesion policy. A place-based approach to meeting European Union challenges and expectations, Independent Report, prepared at the request of Danuta Hübner, Commissioner for Regional Policy.

Becker G. (1990), Ekonomiczna teoria zachowań ludzkich, Publishing House of PWN, Warsaw.

Cebo A., Pawlas K. (2000), Instrumenty i instytucje - wspieranie przedsiębiorczości matych $i$ średnich przedsiębiorstw, [in:] R. Kośmider (ed.), Rola matych i średnich przedsiębiorstw w rozwoju regionalnym, Opole University of Technology and University of Economics and Administration in Bytom, Impuls Publishing House, Krakow.

Chądzyński J. (2014), Udziat podmiotów trzeciego sektora w rozwoju kapitału ludzkiego w regionie łódzkim, [in:] Z. Przygodzkie (ed.), Kapitał ludzki w regionie łódzkim. Społeczeństwo, edukacja, przestrzen, Publishing House of the University of Lodz, Lodz.

Hausner J. (2008), Social Economy Conceptualisation, [in:] The Social Economy And Public Employment Services In Poland - Principles, Prospects And Directions For Cooperation, Social Initiatives Foundation, Warsaw. 
Hausner J. (2006), Systemowe usytuowanie ekonomii społecznej, [in:] J. Hausner (ed.), Ekonomia społeczna jako kategoria rozwoju, Cracow University of Economics, Cracow.

Mertel J. (ed.) (2001), Instrumenty transferu i pobudzania innowacyjności krajowych podmiotów gospodarczych z sektora matych i średnich przedsiębiorstw w perspektywie wejścia Polski do Unii Europejskiej, Incubator Foundation, Lodz.

Jewtuchowicz A. (1997), Środowisko przedsiębiorczości, innowacje a rozwój terytorialny, Publishing House of the University of Lodz, Lodz.

Jewtuchowicz A. (2005), Terytorium i współczesne dylematy jego rozwoju, Publishing House of the University of Lodz, Lodz.

Lamontagne E., Carr A., Stoney Ch. (2011), Place Based Policies: Benefits, Challenges and Opportunities, ISEMA SPECIAL EDITION, Carleton University, Ottawa, Canada.

Markowska M. (2007), Zróżnicowanie europejskiej przestrzeni regionalnej w świetle koncepcji gospodarki opartej na wiedzy, [in:] D. Strahl (ed.), Gospodarka lokalna i regionalna $w$ teorii i praktyce, Research Papers of the Wroclaw University of Economics, Wroclaw No. 1161, Publishing House of the Wroclaw University of Economics, Wroclaw.

Matusiak K.B. (2001), Zasoby i kierunki rozwoju infrastruktury przedsiębiorczości i transferu technologii, [in:] K.B. Matusiak, E. Stawasz, A. Jewtuchowicz, Zewnętrzne determinanty rozwoju innowacyjnych firm, Department of Economics of the University of Lodz, Lodz.

Nowakowska A. (2011), Regionalny wymiar procesów innowacji, Publishing House of the University of Lodz, Lodz.

Ośrodki Innowacji i Przedsiębiorczości w Polsce (1998, 2000, 2001), K.B. Matusiak, T. Niesiołowski (eds.), SOOIPP, Reports.

Pietrzyk I. (2000), Konkurencyjność regionów w ujęciu Komisji Europejskie, [in:] M. Klamut, L. Cybulski (eds.), Polityka regionalna i jej rola w podnoszeniu konkurencyjności regionów, Wroclaw.

Przygodzki Z., Nowakowska A., Sokołowicz M. (2011), Region w gospodarce opartej na wiedzy. Kapitat ludzki - innowacje - korporacje transnarodowe, Difin, Warszawa.

Przygodzki Z. (2013), Polityka rozwoju kapitału ludzkiego w Polsce w perspektywie regionalnej, [in:] Z. Przygodzki (ed.), Regionalny wymiar polityki rozwoju kapitału ludzkiego. Przykład Włoch, Wielkiej Brytanii, Niemiec i Polski, Difin, Warsaw.

Sen A. (2007), On Economic inequality, wydanie rozszerzone, Oxford 1997, [za:] D. Strahl, M. Markowska, Poziom rozwoju gospodarki opartej na wiedzy (GOW) jako podstawa klasyfikacji europejskiej przestrzeni regionalnej, [in:] A. Jewtuchowicz (ed.), Region w gospodarce opartej $n a$ wiedzy, Publishing House of the University of Lodz, Lodz.

Sokołowicz M.E. (2014), Zagadnienie bliskości w badaniach nad rozwojem terytorialnym. Podejście instytucjonalne, [in:] A. Nowakowska (ed.), Zrozumieć terytorium. Idea i praktyka, Publishing House of the University of Lodz, Lodz.

Strahl D., Markowska M. (2007), Poziom rozwoju gospodarki opartej na wiedzy (GOW) jako podstawa klasyfikacji europejskiej przestrzeni regionalnej, [in:] A. Jewtuchowicz (ed.), Region w gospodarce opartej na wiedzy, Publishing House of the University of Lodz, Lodz.

Wygnański J. (2005), Terminologia, [in:] A. Gałązka (ed.), Elementarz III sektora, Stowarzyszenie Klon/Jawor, Warsaw.

Załuska M. (1998), Prawne i organizacyjne ramy działania organizacji pozarzadowych, [in:] M. Załuska, J. Boczoń (eds.), Organizacje pozarządowe w społeczeństwie obywatelskim, Śląsk Publishing House, Katowice. 